\title{
Effect of deformation and annealing temperature on the mechanical properties and microstructure of Al-4.5Zn-1.5Mg-0.9Cr (wt. \%) alloy fabricated by squeeze casting
}

\author{
Maya Putri Agustianingrum, Nuzulian Akbar Arandana, Risly Wijanarko and Bondan Tiara Sofyan ${ }^{1}$ \\ ${ }^{1}$ Department of Metallurgy and Materials Engineering, Faculty of Engineering, Universitas Indonesia, Kampus UI Depok 16424, Indonesia
}

\begin{abstract}
In order to produce structural products, Al-Zn-Mg alloys undergo various forming processes. Problems that are usually found in the forming process include peripheral coarse grain (PCG) and hot tearing which decrease mechanical properties and corrosion resistance of the alloys. Addition of microalloying element such as chromium $(\mathrm{Cr})$ is an alternative to overcome these problems. The presence of $\mathrm{Cr}$ in $\mathrm{Al}-\mathrm{Zn}-\mathrm{Mg}$ alloys supresses the grain growth by preventing excess recrystallization. In this research 0.9 wt. \% $\mathrm{Cr}$ was added to $\mathrm{Al}-4.5 \mathrm{Zn}-1.5 \mathrm{Mg}$ alloy and the deformation behaviour as well as subsequent recrystallization was observed. The alloy was fabricated by squeeze casting followed by homogenization at $400{ }^{\circ} \mathrm{C}$ for $4 \mathrm{~h}$. The samples were cold rolled for 5,10 , and $20 \%$. The $20 \%$ deformed samples were then annealed at 300,400 , and $500{ }^{\circ} \mathrm{C}$ for $2 \mathrm{~h}$. Material characterization consisted of microstructure analysis using optical microscope and Scanning Electron Microscope (SEM) - Energy Dispersive Spectroscopy (EDS), hardness testing using Micro Vicker methods. The results showed that the deformed grain ratio was 1.6, 2.84, and 2.99 in the 5, 10, and $20 \%$ deformed samples, respectively. The elongated dendrites were effective to increase the hardness of the alloy. Recrystallization was not detected during annealing at 300 and $400{ }^{\circ} \mathrm{C}$, but was observed at $500{ }^{\circ} \mathrm{C}$. Whereas, for the samples without $\mathrm{Cr}$ addition, recrystallization occurred at $400{ }^{\circ} \mathrm{C}$. It means that the addition of $\mathrm{Cr}$ increased the recrystallization temperature of the alloy. It occured because ( $\mathrm{Al}, \mathrm{Zn})_{7} \mathrm{Cr}$ dispersoids with size less than $1 \mu \mathrm{m}$ impeded the dislocation motion during annealing, so that recrystallization was retarded. On the other hand $(\mathrm{Al}, \mathrm{Zn})_{7} \mathrm{Cr}$ dispersoids with size more than $1 \mu \mathrm{m}$ promoted the formation of new grains around them by Particle Stimulated Nucleation (PSN) mechanism. In this case, the fine ( $\mathrm{Al}, \mathrm{Zn})_{7} \mathrm{Cr}$ dominated so that recrystallization was slower.
\end{abstract}

\section{Introduction}

Aluminium 7XXX series are alloys with zinc and magnesium as alloying elements. With 83.1 wt. \% solubility in aluminium, addition of zinc enhances the strength of the alloy through solid solution strengthening [1]. While addition of magnesium promotes the $\mathrm{MgZn}_{2}$ precipitate that increases the strength and hardness of the alloy after ageing processes [2]. Thus, these alloys have good mechanical properties and are commonly used in the aircraft industry as small and large components.

Precipitation strengthening in aluminium alloys are achieved through solution treatment and ageing processes [3]. The strength of the alloy can also be further improved by deformation processes, such as extrusion, cold rolling, and drawing. Problems which usually occur during deformation are Peripheral Coarse Grain (PCG) and hot tearing [4]. To overcome the problems, alloying elements such as $\mathrm{Cr}$ are added to the alloys to promote the formation of $\mathrm{CrAl}_{7}$ intermetallic phase [5]. These $\mathrm{Cr}$ intermetallic phases were found to inhibit grain growth and to retard recrystallization during annealing process.

Deformation during cold rolling changes the microstructure and mechanical properties. For aluminium that possesses FCC crystal structure, the deformation mechanism is interesting because of the dependency on the SFE (Stacking Fault Energy). Aluminium alloys have higher SFE than any other FCC metals such as brass and copper, which results in cross slip as common deformation mechanism. Annealing process after cold rolling will lead to recovery, recrystallization and grain growth. Lee \& Kim [6] cold rolled Al7075 by 20, 40 and $60 \%$ and continued with annealing at 300, 400 and 500 ${ }^{\circ} \mathrm{C}$ for $1 \mathrm{~h}$. The results showed that higher deformation led to the increase in nucleation rate during recrystallization so that finer grains were produced and higher strength and hardness were obtained.

This research studied the change in microstructures and hardness of $\mathrm{Al}-4.5 \mathrm{Zn}-1.5 \mathrm{Mg}$ (wt. \%) alloy with addition of 0.9 wt. \% $\mathrm{Cr}$ after various degree of cold rolling followed by annealing process at different temperatures. It was intended to learn how the level of cold rolling reduction affected the deformation mechanism in aluminium alloy and how the annealing temperature affected the recrystallization process. The role of $\mathrm{Cr}$ during deformation and recrystallization process was also investigated. 


\section{Experimental procedure}

Pure $\mathrm{Al}, \mathrm{Zn}$, and $\mathrm{Mg}$ ingots as well as $\mathrm{Al}-80 \mathrm{Cr}$ master alloy (Figure 1) were melted in an electric furnace at 850 ${ }^{\circ} \mathrm{C}$. The molten metal was degassed by argon at $850{ }^{\circ} \mathrm{C}$ at $5000 \mathrm{rpm}$ for $30 \mathrm{~s}$ for proper mixing and then poured into a $300{ }^{\circ} \mathrm{C}$ preheated metal mould with the dimension of $17 \times 17 \times 1.5 \mathrm{~mm}^{3}$. The semi solid metal was squeezed at the pressure of $76 \mathrm{MPa}$ for $10 \mathrm{~min}$. The nominal composition of the as-cast alloy was shown in Table 1. All composition in this paper is in wt. \%, unless otherwise stated. The as-cast alloy then being homogenized in a muffle furnace at the temperature of $400{ }^{\circ} \mathrm{C}$ for $4 \mathrm{~h}$ followed by water quench. Cold rolling was conducted with the degree of deformation of 5, 10 and $20 \%$ in multiple passes. The $20 \%$ deformed samples were then annealed at 300,400 and $500{ }^{\circ} \mathrm{C}$ for $2 \mathrm{~h}$.
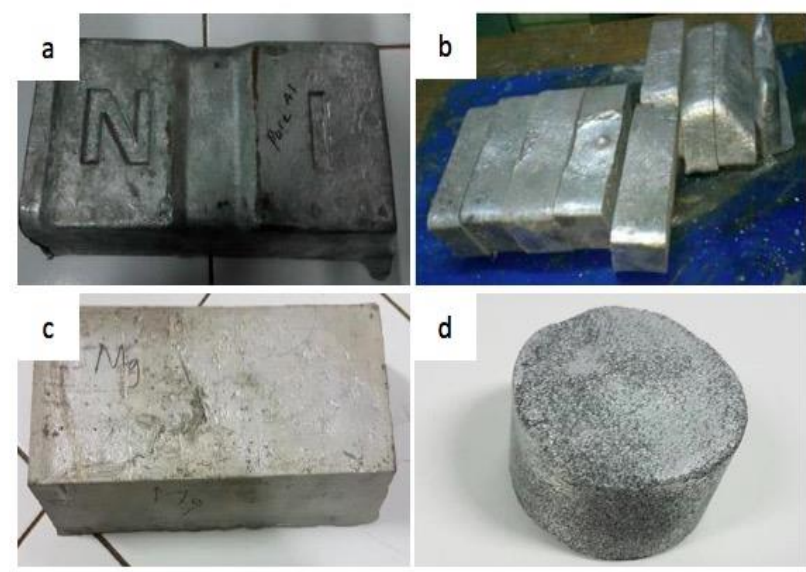

d

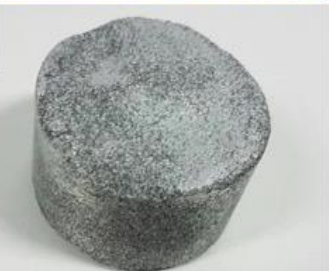

Figure 1. Material used in this research (a) aluminium ingot (b) zinc ingot (c) magnesium ingot and (d) Al-80Cr master alloy.

Table 1. The nominal composition of the Al-4.5Zn-1.5Mg$0.9 \mathrm{Cr}$ (wt. \%) alloy.

\begin{tabular}{cccccccc}
\hline $\mathrm{Zn}$ & $\mathrm{Mg}$ & $\mathrm{Cr}$ & $\mathrm{Fe}$ & $\mathrm{Si}$ & $\mathrm{Cu}$ & $\mathrm{Ni}$ & $\mathrm{Al}$ \\
\hline $\mathbf{4 . 5 6}$ & $\mathbf{1 . 5 1}$ & $\mathbf{0 . 9}$ & 0.21 & 0.13 & 0.01 & 0.02 & $\mathrm{Bal}$. \\
\hline
\end{tabular}

Microstructures were observed by using optical microscope and Scanning Electron Microscope (SEM). Standard metallographic preparation was performed with Keller's etching of $2.5 \mathrm{ml} \mathrm{HNO}_{3}+1 \mathrm{ml} \mathrm{HCl}+1.5 \mathrm{ml} \mathrm{HF}$ $+95 \mathrm{ml}$ distilled water within time span of 60-120 s. The as-homogenized microstructures were further quantitatively analyzed using ImagePro to measure the size of Secondary Dendrite Arm Spacing (SDAS). While Matscope was used to calculate the grain deformation ratio $(\mathrm{L} / \mathrm{d})$ and grain roundness ratio $\left(4 \pi \mathrm{A} / \mathrm{P}^{2}\right)$ on deformed and annealed samples, respectively. Then, Vickers hardness test was performed according to ASTM E384. Five indentations were made for each measurement.

\section{Results and discussion}

\subsection{Deformation Process}

The microstructures of the alloy in as-cast and ashomogenized condition are shown in Figure 2. The ascast microstructure has typical dendritic structure (arrow 1) and tend to be globular because of the applied pressure during squeeze casting process. Bright $\mathrm{Cr}$ intermetallic phase (arrow 3) was found to be sparsely spreaded within the interdendritic structure (arrow 2). The homogenization led to the diffusion of interdendritic phases into the aluminium matrix, which was shown by the decrease in the SDAS from $29.71 \mu \mathrm{m}$ in the as cast condition to $19.86 \mu \mathrm{m}$ in the as-homogenized condition. It also decreased the hardness of the alloy from $121 \mathrm{HV}$ to $104 \mathrm{HV}$ (Figure 2).
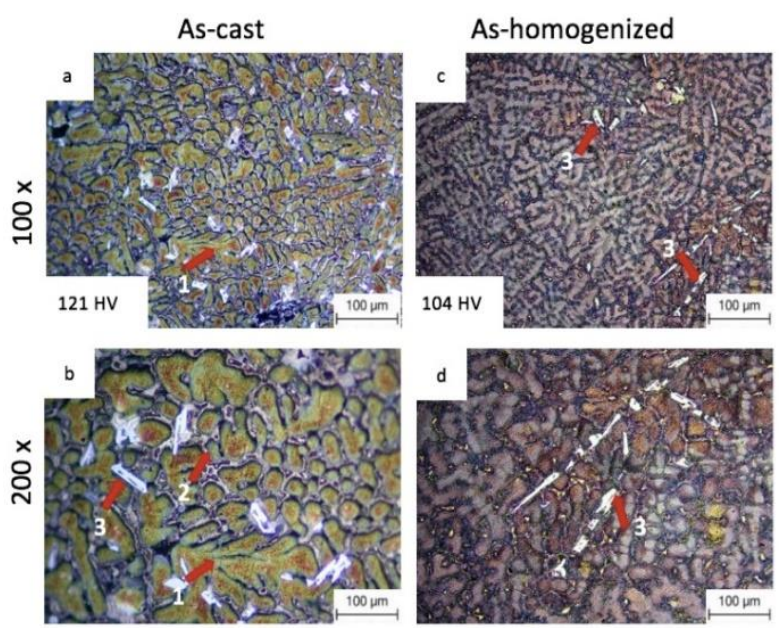

Figure 2. Microstructures of $\mathrm{Al}-4.5 \mathrm{Zn}-1.5 \mathrm{Mg}-0.9 \mathrm{Cr}$ alloy in $(a, b)$ as-cast, and $(d, e)$ as-homogenized condition. Arrows 1, 2 , and 3 point to dendrites, interdendritic and $\mathrm{Cr}$ intermetallic phase, respectively.

Figure 3 shows the comparison between the microstructure of $\mathrm{Al}-4.5 \mathrm{Zn}-1.5 \mathrm{Mg}-0.9 \mathrm{Cr}$ and $\mathrm{Al}-4.7 \mathrm{Zn}$ $1.8 \mathrm{Mg}$ [7] alloys in as-homogenized condition. It is clear that the addition of $0.9 \% \mathrm{Cr}$ reduced the SDAS, therefore increased the hardness from $69.5 \mathrm{HV}$ to $104 \mathrm{HV}$. Refining of SDAS due to addition of $\mathrm{Cr}$ refers to two mechanisms. The first mechanism is Growth Restriction Factor (GRF) due to the presence of $\mathrm{Cr}$ atoms within the aluminium dendrites. The solid solubility of $\mathrm{Cr}$ in $\mathrm{Al}$ is 0.77 wt. $\%$ at $661{ }^{\circ} \mathrm{C}$ [8]. The amount of $\mathrm{Cr}$, which dissolves in $\mathrm{Al}$ matrix, increases the GRF values, as calculated by the following formula [9]:

$$
G R F=m \cdot C o \cdot(k-1)
$$

where $\mathrm{m}$ is liquidus slope, Co is alloy composition, and $\mathrm{k}$ is equilibrium partition coefficient. The calculation showed that the GRF for $0.9 \% \mathrm{Cr}$-added alloy and the base alloy are 9.02 and 6.8, respectively. Therefore $\mathrm{Cr}$ containing alloy might have smaller SDAS.

The second mechanism is heteregenous nucleation by $\mathrm{Cr}$ intermetallic phases (arrow 3 in Figure 1). This is in line with the results by Kumar et al. [10] which found 
that the addition of $\mathrm{Cr}$ in $\mathrm{Al}-\mathrm{Si}-\mathrm{Mg}$ alloys promoted the $\mathrm{Cr}$ intermetallic phases, which then act as heteregenous nucleation sites during solidification and decrease the grain size.

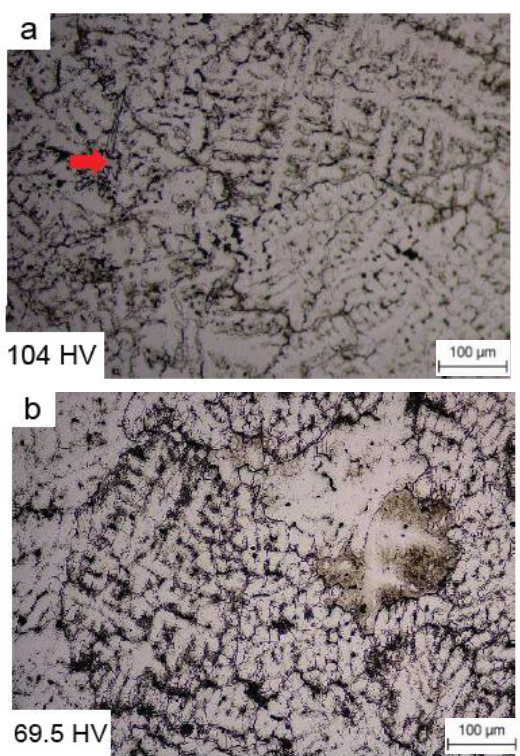

Figure 3. Microstructures of (a) Al-4.5Zn-1.5Mg-0.9Cr and (b) Al-4.7Zn-1.8Mg [7] after homogenization. Red arrow points to $\mathrm{Cr}$ intermetallic phase.

Figure 4 shows the microstructures of $\mathrm{Cr}$-containing alloy and the corresponding base alloy after different degrees of cold rolling and the measured grain deformation ratio $(\mathrm{L} / \mathrm{d})$. After $5 \%$ of deformation, no significant change on the microstructure was observed. The dendrite structures were not much elongated as shown by the L/d ratios of 1.60 and 2.19 in Cr-containing and the base alloys, respectively. No slip lines were observed, indicating that $5 \%$ deformation did not move the dislocations. Significant elongation of dendrites started to occur at $10 \%$ deformation, followed by cracking of $\mathrm{Cr}$ intermetallic phase (Red arrow in Figure 5 (a)). After $20 \%$ deformation, severe elongation of dendrite occured, resulted in L/d ratio of 2.99 and 4.59 in Cr-containing and

the base alloys, respectively. It is noteworthy that the alloy without $\mathrm{Cr}$ shows a series of slip lines (yellow arrow in Figure $4(\mathrm{~h})$ ), while on the other hand they were not detected in the Cr-containing alloy (Figure 4 (d)). This is thought to be due to the presence of incoherent $\mathrm{Cr}$ intermetallics that hinder dislocation movement.

\subsection{Annealing Process}

Figures 4 and 5 show the microstructures of the studied alloys after $20 \%$ of rolling and subsequent annealing at 300,400 , and $500{ }^{\circ} \mathrm{C}$. As illustrated in Figure 5 and 6 (a), $20 \%$ of deformation resulted in elongated dendrites and followed by cracking of $\mathrm{Cr}$ intermetallic. After annealing at $300{ }^{\circ} \mathrm{C}$ for $2 \mathrm{~h}$ (Figure 5 and 6 (b)), the dendrite structure can still be observed but not in elongated shape as before the annealing process. This is in accordance with the calculation of grain roundness ratio, as shown in Table 2. The grain roundness ratio increased from 0.010 to 0.079 after annealed at $300{ }^{\circ} \mathrm{C}$. Increasing of grain roundness ratio indicated the occurrence of recovery process after having extreme deformations due to the previous cold rolling process. However, recrystallization was not occur at this temperature. Meanwhile, the grain roundness ratio increased up to 0.092 after annealing at $400{ }^{\circ} \mathrm{C}$. It can be seen in Figure 5 (c) that the dendrite tips are more rounded than that of before the annealing process. However, the SEM image, as presented in Figure 6 (c), has not shown any recrystallization phenomenon. Furthermore, annealing process at $500{ }^{\circ} \mathrm{C}$ resulted in more rounded dendrites and $\mathrm{Cr}$ intermetallic tips with grain roundness ratio of 0.095 . According to Lee \& Kim [11], stored energy will decrease along with increasing annealing temperature. However, recrystallization was still undetected after annealed at this temperature, as shown in Figure 6 (d). This was due to the addition of $\mathrm{Cr}$ into $\mathrm{Al}-4.5 \mathrm{Zn}-1.5 \mathrm{Mg}$ wt. $\%$ alloy.
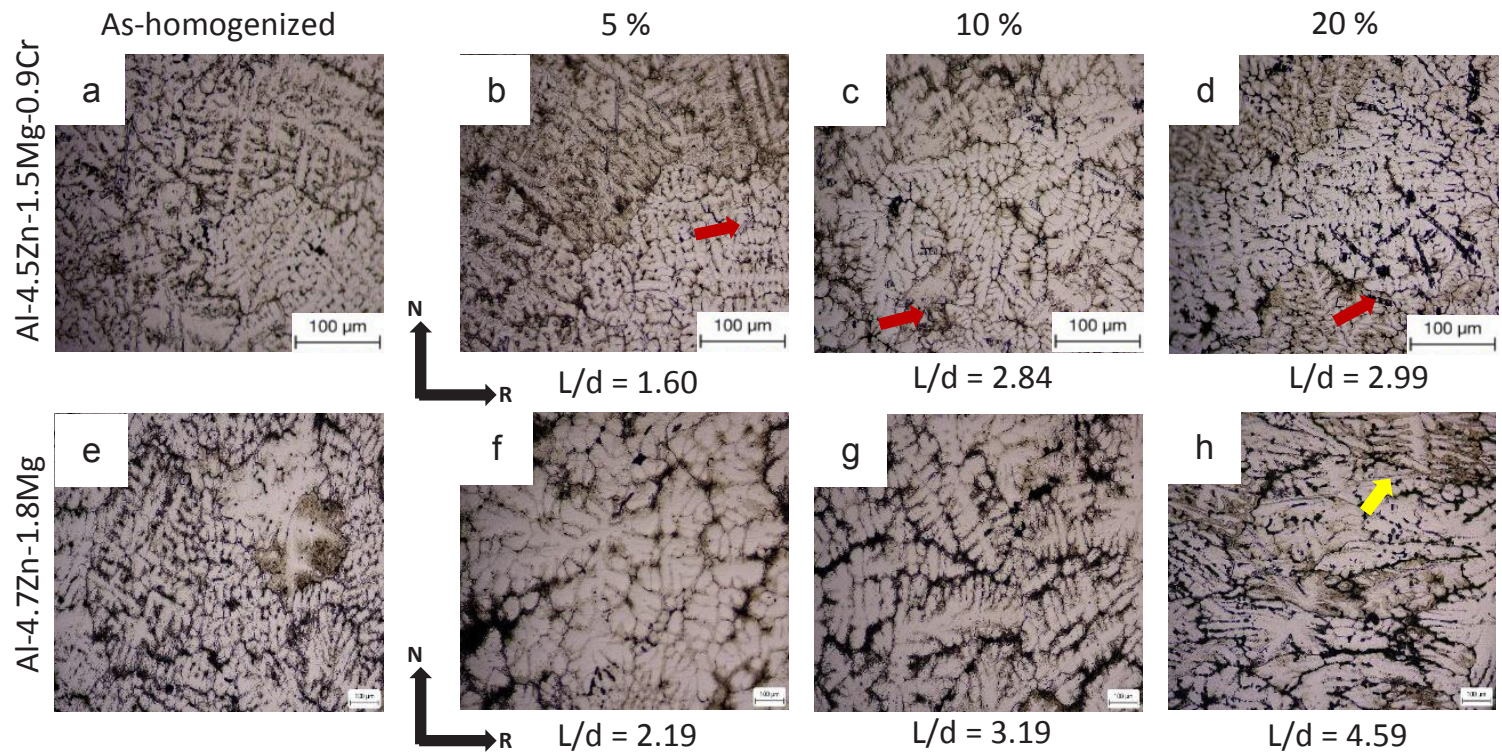

Figure 4. Microstructures of (a-d) Al-4.5Zn-1.5Mg-0.9 Cr and (e-h) Al-4.7Zn-1.8Mg [7] alloys in as-homogenized condition and after cold rolling for 5, 10, and $20 \%$. Red arrow: Cr intermetallic phases, yellow arrow: slip bands, ND: normal direction, RD: rolling direction. 

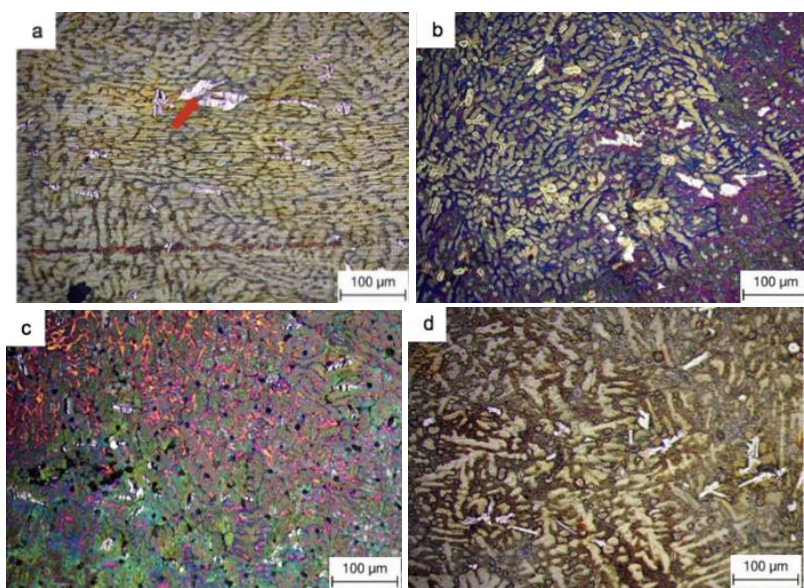

Figure 5. Microstructures of Al- $4.5 \mathrm{Zn}-1.5 \mathrm{Mg}-0.9 \mathrm{Cr}$ alloy after (a) $20 \%$ cold rolling, and subsequent annealing at (b) 300, (c) 400 and (d) $500{ }^{\circ} \mathrm{C}$ for $2 \mathrm{~h}$. Red arrow: cracked Cr intermetallic phases.

Table 2. The comparison of grain roundness ratio of the Al$4.5 \mathrm{Zn}-1.5 \mathrm{Mg}-0.9 \mathrm{Cr}$ alloy before and after cold rolling.

\begin{tabular}{cc} 
Treatment & $\begin{array}{c}\text { Grain } \\
\text { Roundness Ratio } \\
\left(\mathbf{4} \boldsymbol{\pi} \mathbf{A} / \mathbf{P}^{2}\right)\end{array}$ \\
\hline Cold rolling $20 \%$ & 0.010 \\
Cold rolling $20 \%+$ Annealing $300{ }^{\circ} \mathrm{C}$ & 0.079 \\
Cold rolling $20 \%+$ Annealing $400{ }^{\circ} \mathrm{C}$ & 0.092 \\
Cold rolling $20 \%+$ Annealing $500{ }^{\circ} \mathrm{C}$ & 0.095 \\
\hline
\end{tabular}
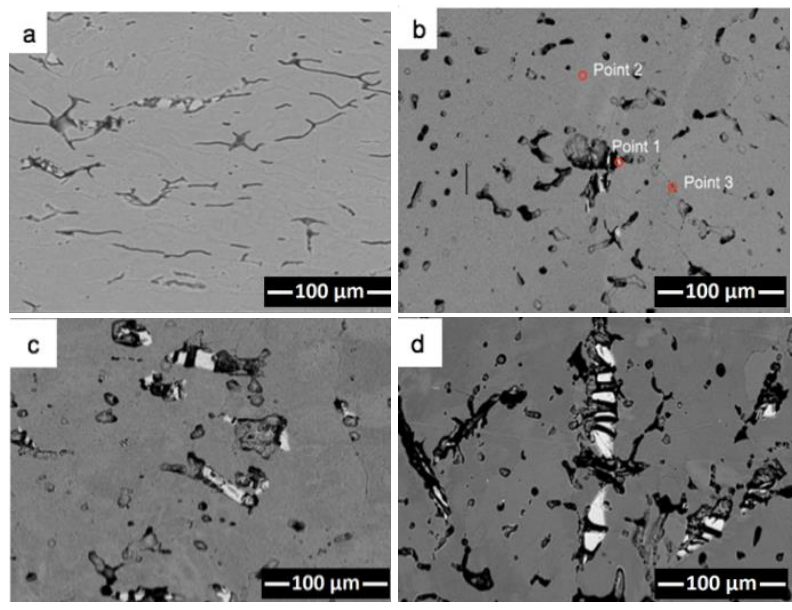

Figure 6. SEM images of Al-4.5Zn-1.5Mg-0.9Cr alloy after (a) $20 \%$ cold rolling, and subsequent annealing at (b) 300, (c) 400 and (d) $500{ }^{\circ} \mathrm{C}$ for $2 \mathrm{~h}$.

Table 3. The composition of the Al-4.5Zn-1.5 Mg- $0.9 \mathrm{Cr}$ alloy after annealing at $300{ }^{\circ} \mathrm{C}$ for $2 \mathrm{~h}$ at positions as shown in Figure $6(\mathrm{~b})$.

\begin{tabular}{cccccc}
\hline \multirow{2}{*}{ Point } & \multicolumn{4}{c}{ Composition (at. \%) } & \multirow{2}{*}{ Possible Phase } \\
\cline { 2 - 5 } & $\mathbf{A l}$ & $\mathbf{Z n}$ & $\mathbf{M g}$ & $\mathbf{C r}$ & \\
\hline 1 & 85.1 & 1.9 & - & 13 & $(\mathrm{Al}, \mathrm{Zn})_{7} \mathrm{Cr}$ \\
2 & 96.2 & 2.3 & 1.6 & - & $\alpha-\mathrm{Al}+\mathrm{MgZn}_{2}$ \\
3 & 96.6 & 1.9 & 1.5 & - & $\alpha-\mathrm{Al}+\mathrm{MgZn}_{2}$ \\
\hline
\end{tabular}

The SEM-EDS results of the studied alloy, which was annealed at $300{ }^{\circ} \mathrm{C}$, are shown in Figure $6(\mathrm{~b})$ and Table 3 . Point 1 indicated $\mathrm{Cr}$ intermetallic in plate-shape, which cracked due to the cold rolling process. The matrix and grain boundary of $\mathrm{Al}-4.5 \mathrm{Zn}-1.5 \mathrm{Mg}-0.9 \mathrm{Cr}$ alloy were observed at point 2 and 3, respectively. As listed in Table
3 , point 2 contained $\alpha-\mathrm{Al}$ with $\mathrm{MgZn}_{2}$ spread in the matrix. Meanwhile, the amount of $\mathrm{Zn}$ and $\mathrm{Mg}$ were also dominant at point 3 , so that $\mathrm{MgZn}_{2}$ existed at the grain boundaries. Point 1 was expected to be the $\mathrm{Cr}$ intermetallic due to the composition that was dominated by aluminium, zinc, and chromium and then formed $(\mathrm{Al}, \mathrm{Zn})_{7} \mathrm{Cr}$. According to $\mathrm{He}$ et al. [12], $\theta$ phase $\left(\mathrm{Al}_{7} \mathrm{Cr}\right)$ contained of 13 at. $\% \mathrm{Cr}, 85$ at. $\% \mathrm{Al}$, and 1.9 at. $\% \mathrm{Zn}$. $(\mathrm{Al}, \mathrm{Zn})_{7} \mathrm{Cr}$ phase can strongly pin dislocation and prevents the formation of new grain boundaries during annealing process due to its high melting point and stable composition. Thus, the existence of $\theta$ phase in the studied alloy increased the recrystallization temperature.

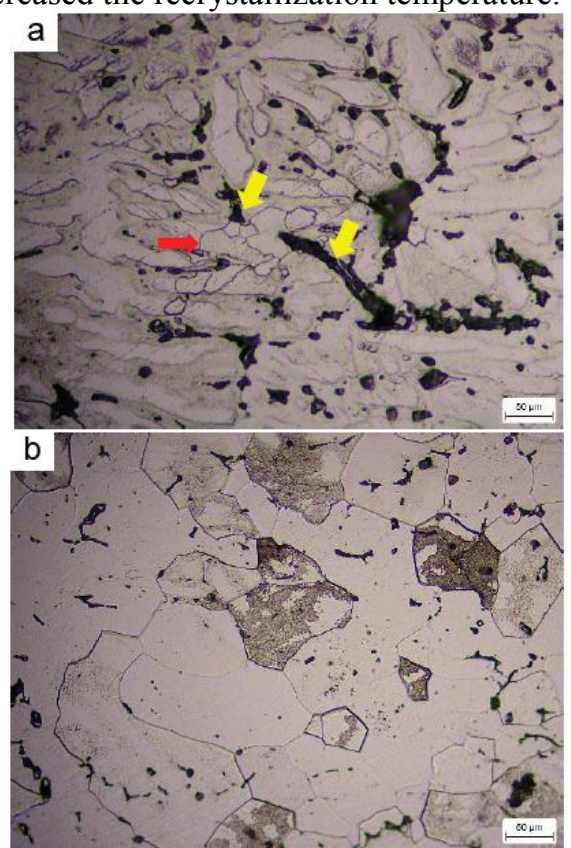

Figure 7. Microstructures of (a) Al-4.5Zn-1.5Mg-0.9Cr and (b) Al-4.7Zn-1.8Mg [7] alloys after annealing at $500{ }^{\circ} \mathrm{C}$ for $2 \mathrm{~h}$. Red arrow: recrystallization, yellow arrow: the deformed $(\mathrm{Al}, \mathrm{Zn})_{7} \mathrm{Cr}$.

Figure 7 presents microstructures of the studied alloys after annealing at $500{ }^{\circ} \mathrm{C}$ for $2 \mathrm{~h}$. As can be seen, $(\mathrm{Al}, \mathrm{Zn})_{7} \mathrm{Cr}$ cracked (yellow arrows) and the cracked boundaries tended to be rounded in Al-4.5Zn-1.5 Mg$0.9 \mathrm{Cr}$ alloy. Meanwhile, grain growth occurred in alloy without $\mathrm{Cr}$ addition. The differences were developed due to the presence of $\mathrm{Cr}$. There are two competing mechanisms work in the Cr-containing alloys due to the formation of $(\mathrm{Al}, \mathrm{Zn})_{7} \mathrm{Cr}$ dispersoids. If the $(\mathrm{Al}, \mathrm{Zn})_{7} \mathrm{Cr}$ possesses size less than $1 \mu \mathrm{m}$, they will pin the dislocations and inhibit grain growth. Liu et al. [13] investigated that the grain growth restriction could effectively occur when $\mathrm{Sc}$ and $\mathrm{Zr}$ intermetallic were in very small sizes $(25 \mathrm{~nm})$. Therefore, the addition of $\mathrm{Cr}$ resulted in higher recrystallization temperature than that of alloy without $\mathrm{Cr}$ addition. However, when the size of $(\mathrm{Al}, \mathrm{Zn})_{7} \mathrm{Cr}$ is $\geq 1 \mu \mathrm{m}$, they will promote nucleation of grains during heating, through Particle Stimulated Nucleation (PSN) mechanism. This is clear in Figure 7 (a), where nucleation of new grains was detected around $(\mathrm{Al}, \mathrm{Zn})_{7} \mathrm{Cr}$ (red arrow). This phenomenon is in line with Sidor et al. [14], which represented nucleation in AA 5182 alloy by PSN mechanism after cold rolling and 
annealing at $550{ }^{\circ} \mathrm{C}$. When we compare Figure 7 (a) and (b), of which grain growth was inhibited in the $\mathrm{Cr}$ containing alloy, it is clear that the grain growth retardation by fine $(\mathrm{Al}, \mathrm{Zn})_{7} \mathrm{Cr}$ is more dominant than the PSN mechanism by large $(\mathrm{Al}, \mathrm{Zn})_{7} \mathrm{Cr}$ dispersoids.

The effect of annealing temperature on the hardness of Al-4.5Zn-1.5 Mg-0.9Cr alloy is shown in Figure 8 . Before annealing, the hardness value reached $117.16 \mathrm{HV}$ and significantly decreased to $86.84 \mathrm{HV}$ after annealing at $300{ }^{\circ} \mathrm{C}$ due to the recovery of interlocking dislocations. Annealing at $400{ }^{\circ} \mathrm{C}$ further increased the hardness to $110.90 \mathrm{HV}$, which indicated the recrystallization process. However, the microstructure presents the absence of nucleation, as shown in Figure 5 (c). The hardness value continued to increase up to $117.43 \mathrm{HV}$, which implied recrystallization started to occur (Figure 7 (a)). Furthermore, increased hardness also caused by the pinning effect of $(\mathrm{Al}, \mathrm{Zn})_{7} \mathrm{Cr}$ in the studied alloy, which restricted the grain boundaries and dislocation movement during the annealing process. These results correspond to Liu et al. [13], which investigated increasing hardness up to $51.96 \%$ after the addition of $0.10 \mathrm{wt} \% \mathrm{Sc}$ and 0.16 wt. \% Zr. Meanwhile, the hardness of Al-4.7Zn-1.8Mg wt. \% before annealing was lower than that of alloy with $\mathrm{Cr}$ addition with the value of $102.90 \mathrm{HV}$. After annealing at $300{ }^{\circ} \mathrm{C}$, the hardness decreased to $95.7 \mathrm{HV}$, which was higher compared with alloy with $\mathrm{Cr}$ addition. Higher annealing temperature shows a continued decrease down to $94.1 \mathrm{HV}$. This was due to the absence of grain growth restriction by $\mathrm{Cr}$.

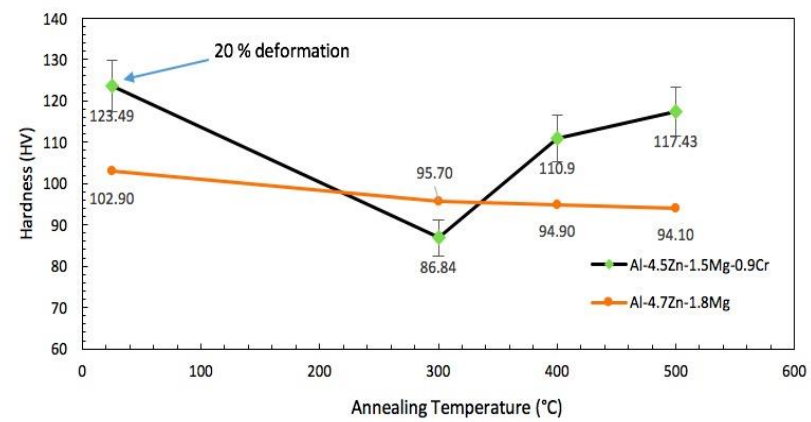

Figure 8. Effect of annealing temperature on the hardness of the $20 \%$ deformed Al-4.5Zn-1.5Mg- $0.9 \mathrm{Cr}$ compared with Al$4.7 \mathrm{Zn}-1.8 \mathrm{Mg}$ alloys [6].

\section{Conclusions}

The results of investigation on $\mathrm{Al}-4.5 \mathrm{Zn}-1.5 \mathrm{Mg}-0.9 \mathrm{Cr}$ (wt. \%) alloy can be concluded as follow:

1. The hardness of as-cast $\mathrm{Al}-4.5 \mathrm{Zn}-1.5 \mathrm{Mg}-0.9 \mathrm{Cr}$ alloy was $121 \mathrm{HV}$ and then decreased to $104 \mathrm{HV}$ after homogenization process due to the diffusion of interdendritic phase to the $\alpha-\mathrm{Al}$ matrix.

2. The $5 \%$ deformed $\mathrm{Al}-4.5 \mathrm{Zn}-1.5 \mathrm{Mg}-0.9 \mathrm{Cr}$ alloy did not indicate any plastic deformation. The dendrite structure was further elongated followed by the cracking of $(\mathrm{Al}, \mathrm{Zn})_{7} \mathrm{Cr}$ intermetallic phase after $10 \%$ and $20 \%$ of deformation. The grain deformation ratio after cold rolling for 5, 10, and $20 \%$ are 1.6, 2.84 , and 2.99 , respectively.

3. The hardness value of $\mathrm{Al}-4.5 \mathrm{Zn}-1.5 \mathrm{Mg}-0.9 \mathrm{Cr}$ alloy with variation of 5,10 , and $20 \%$ deformation are
105.95, 118.75, and 117.16 HV, respectively, which hardening mechanism was strain hardening.

4. Annealing process at 300 and $400{ }^{\circ} \mathrm{C}$ on $\mathrm{Al}-4.5 \mathrm{Zn}$ $1.5 \mathrm{Mg}-0.9 \mathrm{Cr}$ alloy has not changed the dendritic structure, while the intermetallic tips were more rounded. After annealing at $500{ }^{\circ} \mathrm{C}$, local recrystallization started to occur. The grain roundness ratio after annealing at 300, 400, and 500 ${ }^{\circ} \mathrm{C}$ were $0.079,0.092$, and 0.095 , respectively.

5. The presence of $\mathrm{Cr}$ promotes the formation of $(\mathrm{Al}, \mathrm{Zn})_{7} \mathrm{Cr}$ intermetallic phase.

6. $(\mathrm{Al}, \mathrm{Zn})_{7} \mathrm{Cr}$ with size smaller than $1 \mu \mathrm{m}$ restricted the dislocation movement and grain boundaries migration. Meanwhile, $(\mathrm{Al}, \mathrm{Zn})_{7} \mathrm{Cr}$ intermetallic phase with size more than $1 \mu \mathrm{m}$ initiated nucleation with the mechanism of Particle Stimulated Nucleation (PSN). In the studied alloy, fine $(\mathrm{Al}, \mathrm{Zn})_{7} \mathrm{Cr}$ dominated so that recrystallization was slower.

7. Increasing annealing temperature generated increasing hardness values, which are 86.84, 110.9, and $117.43 \mathrm{HV}$ on annealing temperatures of 300 , 400 , and $500{ }^{\circ} \mathrm{C}$, respectively.

\section{Acknowledgement}

The authors are grateful with the provision of research funding through Hibah Publikasi Internasional Terindeks untuk Tugas Akhir (PITTA) 2017 from Universitas Indonesia.

\section{References}

1. Agrawal, L., Yadav, R., \& Sexena, A. Effect of Magnesium Content on the Mechanical Properties of Al-Zn-Mg Alloys. Int. J. of Em. Tech., 3, 137-140 (2012)

2. He, Z., Su, X., Peng, H., Liu, Y., Wu, C., \& Wang, J. $600{ }^{\circ} \mathrm{C}$ Isothermal Section of the Al-Cr-Zn Ternary Phase Diagram. J. Alloys and Compounds., 649, 1239-1245 (2015).

3. Prabhukhot, A. Effect of Heat Treatment on Hardness and Corrosion Behavior of 6082-T6 Aluminium Alloy in Artificial Sea Water. Int. J. of Materials Science and Engineering., 3, 287-294 (2015).

4. Eivani, A. R., Zhou, J., \& Duszczyk, J. Recent Trends in Processing and Degradation of Aluminium Alloys. Rijeka: InTech. (2011).

5. Rooy, E. L. Aluminium Alloy Castings: Properties, Processes, and Applications. Detroit: ASM International Committee. (2004).

6. Lee, Y. S., \& Kim, W. K. Recrystallization behavior of cold rolled $\mathrm{Al}-\mathrm{Zn}-\mathrm{Mg}-\mathrm{Cu}$ fabricated by twin roll casting. Trans. Nonferrous Met. Soc. China., 24, 2226-2231 (2014).

7. Kurnia, R., \& Sofyan, B.T., Effect of Cold Rolling and Annealing Temperature on The Recrystallization and Mechanical Properties of Al-4.7Zn-1.8Mg (wt. \%) Alloy Fabricated by Squeeze Casting. Proc. Int.Conf. QiR., 1-6 (2017). 
8. Rambabu, P., Prasad, N., Kutumbarao, V. \& Wanhill, R. ed., Aluminium Alloys for Aerospace Applications. In: Aerospace Materials and Material Technologies, 1st ed. Indian Institute of Metals Series, 36 (2017).

9. Zhang, L., Eskin, D., Miroux, A. \& Katgerman, L. Role of Solute and Transition Metals in Grain Refinement of Aluminium Alloys Under Ultrasonic Melt Treatment. TMS (The Minerals, Metals \& Materials Society), 1389-1394 (2012).

10. Kumar, A., Sharma, G., \& Sasikumar, A. Effect of $\mathrm{Cr}$ on grain refinement and mechanical properties of Al$\mathrm{Si}-\mathrm{Mg}$ alloys. Applied Mechanics and Materials., 789-790, 95-99 (2015).

11. Lee, Y. S., \& Kim, W. K. Recrystallization behavior of cold rolled $\mathrm{Al}-\mathrm{Zn}-\mathrm{Mg}-\mathrm{Cu}$ fabricated by twin roll casting. Trans. Nonferrous Met. Soc. China., 24, 2226-2231 (2014)
12. He, Z., Su, X., Peng, H., Liu, Y., Wu, C., \& Wang, J. $600{ }^{\circ} \mathrm{C}$ Isothermal Section of the Al-Cr-Zn Ternary Phase Diagram. J. of Alloys and Comp., 649, 12391245 (2015).

13. Liu, J., Yao, P., Zhao, N., Shi, C., Li, H., Li, X., Xi, D., \& Yang, S. Effect of minor Sc and $\mathrm{Zr}$ on recrystallization behavior and mechanical properties of novel Al-Zn-Mg-Cu alloys. J. Alloys and Compounds., 657, 717-725 (2016).

14. Sidor, J.J., Decroos, K., Petrov R.H., \& Kestens L.A.I. Particle Stimulated Nucleation in Severely Deformed Aluminium Alloys. Materials Science Forum., 706-709, 389-394 (2012). 